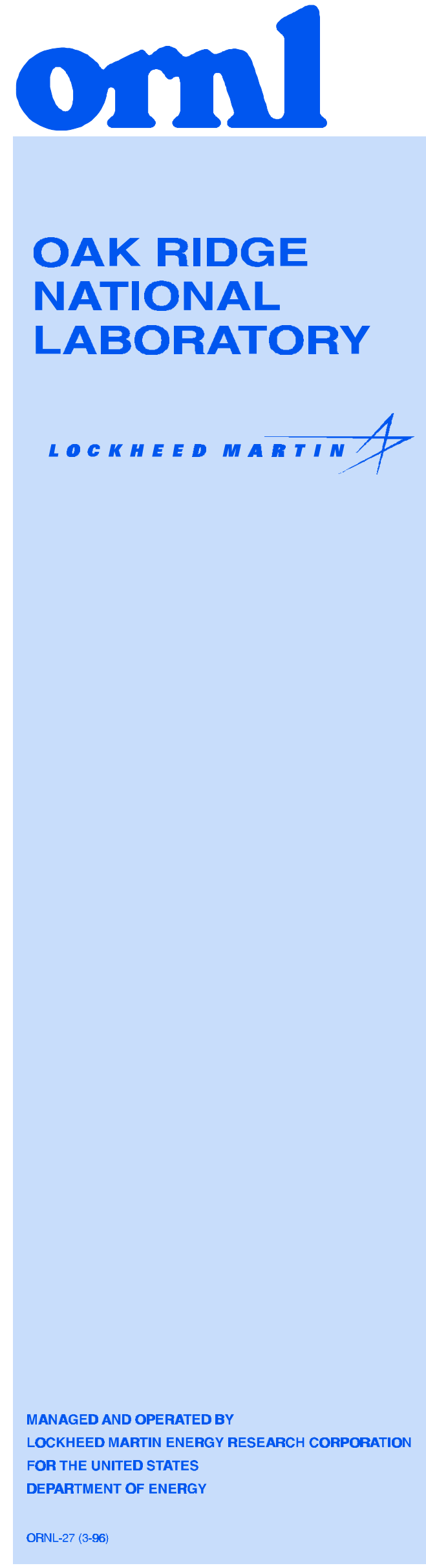

B. D. Murphy

\title{
Prediction of the Isotopic Composition of $\mathrm{UO}_{2}$ Fuel from a BWR: Analysis of the DU1 Sample from the Dodewaard Reactor
}

\author{
B. D. Murphy
}


This report has been reproduced directly from the best available copy.

Available to DOE and DOE contractors form the Office of Scientific and Technical Information, P.O. Box 62, Oak Ridge, TN 37831; prices available from (615) $576-8401$.

Available to the public from the National Technical Information Service, U.S. Department of Commerce, 5285 Port Royal Rd., Springfield, VA 22161.

This report was prepared as an account of work sponsored by an agency of the United States Government. Neither the United States nor any agency thereof, nor any of their employees, makes any warranty, express or implied, or assumes any legal liability or responsibility for the accuracy, completeness, or usefulness of any information, apparatus, product, or process disclosed, or represents that its use would not infringe privately owned rights. Reference herein to any specific commercial product, process, or service by trade name, trademark, manufacturer, or otherwise, does not necessarily constitute or imply its endorsement, recommendation, or favoring by the United States Government or any agency thereof. The views and opinions of authors expressed herein do not necessarily state or reflect those of the United States Government or any agency thereof. 


\title{
Prediction of the Isotopic Composition of $\mathrm{UO}_{2}$ Fuel from a BWR: Analysis of the DU1 Sample from the Dodewaard Reactor
}

\author{
B. D. Murphy
}

Date Published: October 1998

Prepared by the

OAK RIDGE NATIONAL LABORATORY

P.O. Box 2008

Oak Ridge, Tennessee 37831-6370

managed by

LOCKHEED MARTIN ENERGY RESEARCH CORP.

for the

U.S. DEPARTMENT OF ENERGY

under contract DE-AC05-96OR22464 



\section{CONTENTS}

Page

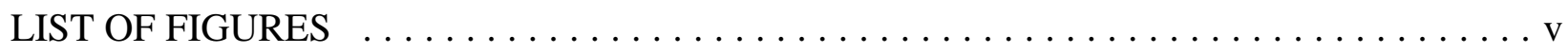

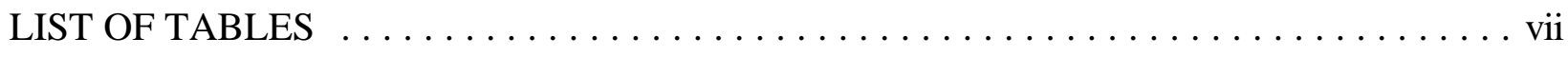

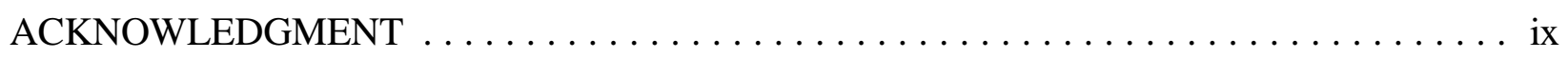

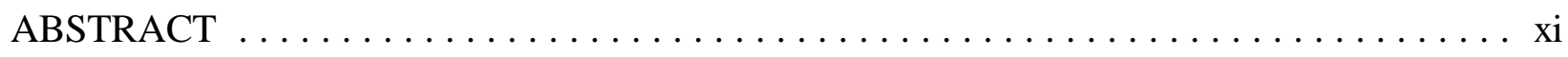

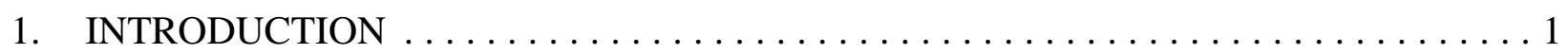

2. DESCRIPTION OF FUEL ASSEMBLY AND SAMPLE BURNUP $\ldots \ldots \ldots \ldots \ldots 3$

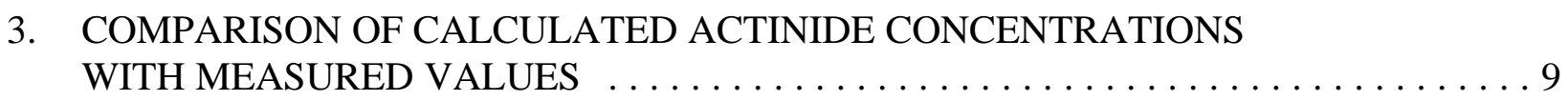

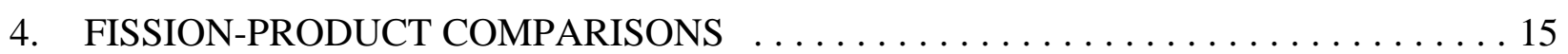

5. $\quad$ SENSITIVITY TO BURNUP AND MODERATOR DENSITY $\ldots \ldots \ldots \ldots \ldots \ldots 17$

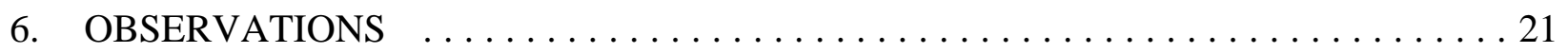

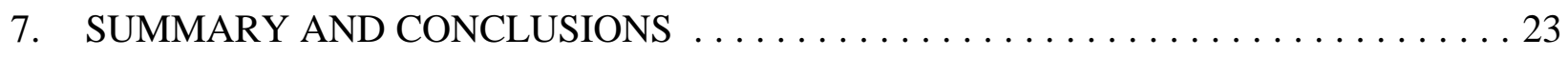

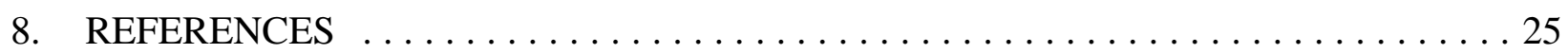





\section{LIST OF FIGURES}

Figure

Page

1. The Dodewaard BWR experimental assembly $\ldots \ldots \ldots \ldots \ldots \ldots \ldots \ldots \ldots$

2. Calculated-to-experimental ratios for the DU1 sample actinides $\ldots \ldots \ldots \ldots \ldots$

3. A schematic representation of the relevant actinides $\ldots \ldots \ldots \ldots \ldots \ldots \ldots \ldots$

4. Calculated concentrations for DU1 actinides shown relative to one another

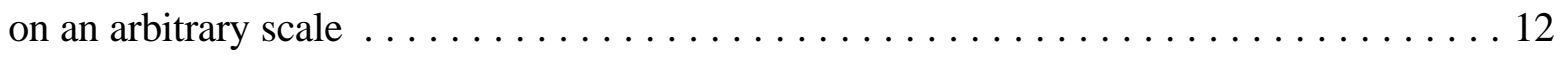

5. Calculated-to-experimental ratios for fission products in DU1 sample $\ldots \ldots \ldots \ldots \ldots$

6. Sensitivity of the ${ }^{235} \mathrm{U}$ and ${ }^{239} \mathrm{Pu}$ concentrations to burnup in the DU1 sample. . . . . . . . 18

7. Calculated-to-experimental ratios for the DU1 actinides using the operator estimate of burnup . . . . . . . . . . . . . . . . . 19

8. Sensitivity of the ${ }^{235} \mathrm{U}$ and ${ }^{239} \mathrm{Pu}$ concentrations to the moderator density in SAS2H. . . . 20 


\section{LIST OF TABLES}

Table

Page

$1 \quad$ Fuel assembly parameters for the Dodewaard BWR $\ldots \ldots \ldots \ldots \ldots \ldots \ldots \ldots$

2. Zones for the SAS2H model $\ldots \ldots \ldots \ldots \ldots \ldots \ldots \ldots \ldots \ldots \ldots \ldots \ldots \ldots \ldots \ldots \ldots$

$3 \quad$ Power history for the DU1 sample irradiation $\ldots \ldots \ldots \ldots \ldots \ldots \ldots \ldots \ldots$

$4 \quad$ Calculated-to-experimental ratios for DU1 actinides $\ldots \ldots \ldots \ldots \ldots \ldots \ldots \ldots$ 


\section{ACKNOWLEDGMENT}

The author acknowledges the many enlightening technical discussions with R. Trent Primm III on the subject of this report and related matters. The insight provided by three other ORNL colleagues - Bryan Broadhead, Mark DeHart, and Cecil Parks - on the modeling of burnup in BWRs is greatly appreciated. These analyses and documentation were funded by the U.S. Department of Energy, Office of Radioactive Waste, and by the U.S. Department of Energy, Yucca Mountain Site Characterization Office.

The data analyzed and reported here are from an international program called ARIANE. This program is managed by Belgonucleaire, Inc. As of the publication of this document, the ARIANE program is ongoing. By contractual agreement, Lockheed Martin Energy Research Corporation, the managing contractor for the Oak Ridge National Laboratory, cannot release ARIANE data to nonprogram participants until two years following the completion of the program. However, by agreement, calculation-to-experiment comparisons can be reported in the open literature. This report does not contain any data generated under the ARIANE program nor can such data be reconstructed from information contained in this report. 



\begin{abstract}
As part of a larger program to study mixed-oxide fuel subject to high burnup, some $\mathrm{UO}_{2}$ samples were exposed and analyzed. This report discusses results from the analysis of a $\mathrm{UO}_{2} \mathrm{sample}$ that was burned in a boiling-water reactor (BWR) to approximately $57 \mathrm{GWd} / \mathrm{t}$. The sample enrichment was high ( ${ }^{235} \mathrm{U}$ content of $4.94 \%$ ) relative to the surrounding $\mathrm{UO}_{2}$ fuel. The isotopic content of the discharged sample was determined experimentally (both actinides and fission products), and the measured concentrations are compared with calculated values using both the Oak Ridge National Laboratory SCALE system and the HELIOS code system that is marketed by Scandpower. Because the sample enrichment differed from that of the surrounding fuel, this test was a rather stringent test of the simulation models. These results are discussed, as are the general issues surrounding the simulation of fuel burnup in a BWR.
\end{abstract}





\section{INTRODUCTION}

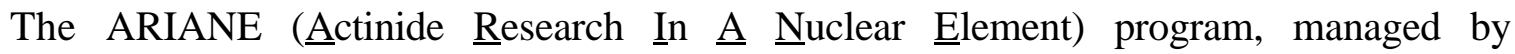
Belgonucleaire, has as its primary purpose to understand the isotopic composition of mixed-oxide (MOX) fuel discharged from light-water reactors (LWRs). However, some $\mathrm{UO}_{2}$ fuel samples are also being studied as part of the ARIANE program. Fuel samples were irradiated in both boiling-water reactor (BWR) and pressurized-water-reactor (PWR) assemblies, and radiochemical analyses were performed on the samples following discharge. At Oak Ridge National Laboratory (ORNL), the burnup of these samples was simulated using both the ORNL SCALE system ${ }^{1}$ and the HELIOS code ${ }^{2}$ developed by Scandpower. The work being reported here involves a BWR. The SCALE approach (using the SAS2H sequence) is a point-depletion calculation with neutron spectra and cross sections vs burnup determined via a one-dimensional (1-D) transport model. HELIOS, on the other hand, is a two-dimensional (2-D) lattice code.

In the ARIANE program to date, preliminary experimental measurement data have been obtained for two MOX samples and one $\mathrm{UO}_{2}$ sample from a BWR. In this report we document preliminary results for the $\mathrm{UO}_{2}$ sample. We will present comparisons between isotopic concentration predictions obtained with the ORNL and Scandpower computer codes and experimental measurements performed by a Belgian radiochemical laboratory. Under the terms of agreement among the ARIANE participants, the actual measured values cannot be released to the public at this time. All measurement data that are discussed here are preliminary. However, significant adjustments are not anticipated.

The $\mathrm{UO}_{2}$ sample, contained in a BWR assembly (that was composed mostly of $\mathrm{UO}_{2}$ fuel), was exposed to a burnup of approximately $57 \mathrm{GWd} / \mathrm{t}$. Measured concentrations have been reported for actinides from ${ }^{234} \mathrm{U}$ to ${ }^{246} \mathrm{Cm}$, as well as for 26 fission products between ${ }^{106} \mathrm{Ru}$ and ${ }^{155} \mathrm{Eu}$. Comparisons between the calculated and measured concentrations give a good indication of the ability to predict the isotopic composition of $\mathrm{UO}_{2}$ fuel burned in a BWR. Because the BWR assembly was composed primarily of $\mathrm{UO}_{2}$ fuel, the results from the $\mathrm{UO}_{2}$ sample can be considered indicative of the assembly in general. The MOX fuel samples, present in the same assembly as the $\mathrm{UO}_{2}$ pins, represent a much

more unique situation, and the results are being subjected to a more detailed analysis. They will be reported at a later date. 



\section{DESCRIPTION OF FUEL ASSEMBLY AND SAMPLE BURNUP}

The $\mathrm{UO}_{2}$ sample described here was burned in a BWR at Dodewaard, Gelderland, in the Netherlands. This particular BWR was rated at $183 \mathrm{MWt}$. The core contained 164 assemblies. Each assembly contained a $6 \times 6$ lattice of a design described as GE/RDM. Figure 1 is a schematic view of the arrangement of the fuel elements in the assembly that contained the experimental samples. Three assembly pin locations were reserved for the experimental samples: one for the $\mathrm{UO}_{2}$ and two for the MOX. The one $\mathrm{UO}_{2}$ sample is referred to as DU1; the two MOX samples are known as DM1 and DM2. In Fig. 1, a cruciform control blade is indicated towards the top left of the assembly. The modeling approaches described do not include the control blades because information on the control blades is not currently available. This information will be supplied by Belgonucleaire. The assembly also contained a Zircaloy flow box that was included in the simulation, as was that part of the surrounding moderator associated with the assembly.

The uranium fuel sample contained ${ }^{235} \mathrm{U}$ and ${ }^{238} \mathrm{U}$; the ${ }^{235} \mathrm{U}$ content was 4.94 wt \%. Although these are the only uranium isotopes that were quoted, it is likely that there was also some ${ }^{234} \mathrm{U}$ and ${ }^{236} \mathrm{U}$ present in the fresh fuel sample. Most of the relevant parameters used in modeling the assembly are given in Table 1. Note that Table 1 describes four types of fuel rods: two types of standard uranium rods (one with just $\mathrm{UO}_{2}$ and the other with $\mathrm{UO}_{2}$ and gadolinium oxide), the MOX experimental-sample rods, and the $\mathrm{UO}_{2}$ experimental-sample rod. Note also that (1) the uranium enrichment varies between the standard $\mathrm{UO}_{2}$ rods, and (2) the radial dimensions of the experimentalsample rods are different from those of the standard rods.

The DU1 sample was located at about three-quarters of the assembly height from the bottom of the assembly. The moderator density used in the simulations corresponded to the time-averaged density at this height. It would be possible to use a more detailed history of moderator density. Such data (which are proprietary) are available. However, in a practical situation, a simulation model would be used to analyze spent reactor fuel, where scant information may be available on moderator density history. We are endeavoring here to indicate how well one can model under such circumstances. The $\mathrm{UO}_{2}$ rod containing the $\mathrm{UO}_{2}$ sample was surrounded by other fuel rods that were also composed of $\mathrm{UO}_{2}$ fuel. This arrangement makes the modeling of this sample an acceptable candidate for the SAS2H sequence from the SCALE system, which is designed to give volumeaveraged results. In the model constructed for this exercise, the assembly is assumed to have similar fuel, clad, and moderator composition in the axial direction, and the model is, in effect, infinite in the axial direction. However, in this exercise it is just the behavior of the assembly at the axial location of the DU1 sample that is being simulated.

An instrument-tube hole, located towards the center of the assembly, contains just moderator and Zircaloy (identified as an empty hole in Fig. 1). Because the assembly has an even number of elements on a side, this hole is not at the exact center. A typical approach with SAS2H is to model such a hole as being at the geometric center of the assembly, and this approach was used in this instance. The model prepared for SAS2H consisted of several zones. The innermost region was the central instrument-tube hole composed of water, Zircaloy, and water zones in that order. The water inside the Zircaloy was assumed to be of the appropriate density for the temperature at the sample location $(573 \mathrm{~K})$. It was not considered to be boiling, so no void fraction was assumed. The water 
outside the Zircaloy in this central region was assigned a void fraction, as was all of the water inside the Zircaloy box containing the assembly. The average void fraction (at the sample location) for the five reactor cycles was, in order, $0.534,0.525,0.544,0.473$, and 0.422 . The innermost region described above was surrounded by the fuel zone. A zone of gadolinium oxide surrounded the fuel zone to account for the gadolinium oxide that is in five of the fuel pins. The gadolinium oxide zone was surrounded by a Zircaloy zone to represent the Zircaloy box surrounding the assembly. The outermost zone represented the channel moderator. It was composed of water at a temperature of $573 \mathrm{~K}$, but with no void fraction. The dimensions of the zones in the SAS2H model are shown in Table 2.

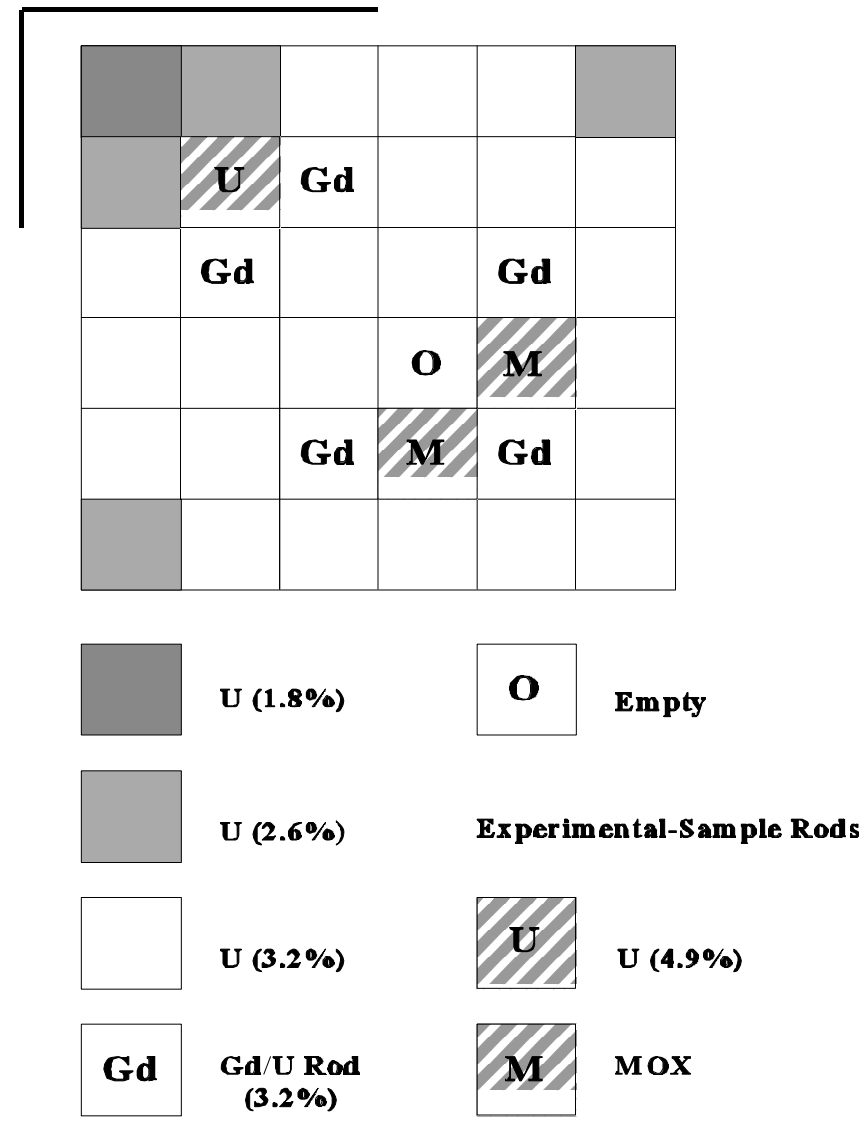

Fig. 1. The Dodewaard BWR experimental assembly. The weight percentages of fissile uranium are given in parentheses. The fuel-rod pitch is $1.793 \mathrm{~cm}$. 
Table 1. Fuel assembly parameters for the Dodewaard BWR

\begin{tabular}{|c|c|c|c|c|}
\hline Characteristics & $\begin{array}{c}\mathrm{UO}_{2} \\
\text { standard rod }\end{array}$ & $\begin{array}{c}\mathrm{UO}_{2} / \mathrm{Gd}_{2} \mathrm{O}_{3} \\
\text { standard rod }\end{array}$ & $\begin{array}{c}\text { MOX } \\
\text { sample rod }\end{array}$ & $\begin{array}{c}\mathrm{UO}_{2} \\
\text { sample rod }\end{array}$ \\
\hline \multicolumn{5}{|l|}{$\underline{\text { Pellet }}$} \\
\hline - Material & $\mathrm{UO}_{2}$ & $\mathrm{UO}_{2} / \mathrm{Gd}_{2} \mathrm{O}_{3}$ & $\mathrm{UO}_{2}-\mathrm{PuO}_{2}$ & $\mathrm{UO}_{2}$ \\
\hline - Approximate density (\% TD) & 95 & 95 & 94 & 95 \\
\hline - Approximate diameter (mm) & 11 & 11 & 10 & 10 \\
\hline - $\mathrm{Pu} /(\mathrm{U}+\mathrm{Pu})(\mathrm{wt} \%)$ & - & - & 6.4 & - \\
\hline - $\mathrm{Gd} / \mathrm{U}(\mathrm{wt} \%)$ & - & 2.7 & - & - \\
\hline \multicolumn{5}{|l|}{ - Isotopic compositions (wt \%) } \\
\hline${ }^{235} \mathrm{U} / \mathrm{U}$ & $3.2 / 2.6 / 1.8$ & 3.2 & 0.239 & 4.941 \\
\hline${ }^{239} \mathrm{Pu} / \mathrm{Pu}$ & - & - & 61.844 & - \\
\hline${ }^{240} \mathrm{Pu} / \mathrm{Pu}$ & - & - & 23.380 & - \\
\hline $\begin{array}{l}\text { - Approximate oxide linear } \\
\text { weight }(\mathrm{g} / \mathrm{cm})\end{array}$ & 11 & 10 & 9 & 9 \\
\hline \multicolumn{5}{|l|}{ Cladding } \\
\hline - Material & $\mathrm{Zr}-2$ & $\mathrm{Zr}-2$ & $\mathrm{Zr}-2$ & $\mathrm{Zr}-2$ \\
\hline - Inner diameter (mm) & 11.71 & 11.71 & 10.55 & 10.55 \\
\hline - Outer diameter (mm) & 13.49 & 13.49 & 12.27 & 12.27 \\
\hline
\end{tabular}


Table 2. Zones for the SAS2H model. The area of each zone is equal to the actual area of that material in the assembly

\begin{tabular}{cccc}
\hline Zone & Material & Area $\left(\mathrm{cm}^{2}\right)$ & Outer radius $(\mathrm{cm})$ \\
\hline 1 & Water & 1.077 & 0.5855 \\
2 & Zircaloy & 0.3523 & 0.6745 \\
3 & Water (with voids) & 1.7856 & 1.0116 \\
4 & Fuel mixture & 112.52 & 6.0696 \\
5 & Gadolinia & 1.0 & 6.0957 \\
6 & Water film & 5.422 & 6.2357 \\
7 & Zircaloy & 7.6631 & 6.4283 \\
8 & Outside water moderator & 32.47 & 7.1874 \\
\hline
\end{tabular}

The fuel in the fuel mixture zone (zone 4) of Table 2 is assumed to be $\mathrm{UO}_{2}$ similar in composition to the analyzed $\mathrm{UO}_{2}$ sample that is designated as " $\mathrm{U}$ " in Fig.1 (second lattice position from the left in the second row from the top). The actual assembly contained primarily $\mathrm{UO}_{2}$ fuel, although with some variations in enrichment. However, when exercising SAS2H, only one fuel mix can be specified. Therefore, neither the variations in $\mathrm{UO}_{2}$ fuel enrichment nor the MOX fuel are included as part of the SAS2H modeling discussed here. The pin-cell dimensions used for the SAS2H path-A simulations were those given in Table 1 for the $\mathrm{UO}_{2}$ sample. Table 2, of course, gives the dimensions of the zones used in the SAS2H path-B simulation. One can see that a water hole was specified at the center as was discussed earlier surrounded by a fuel zone. The gadolinium was modeled as follows: The specifications quoted gadolinium as being present at $2.7 \mathrm{wt} \%$ of the uranium in the rods containing uranium and gadolinium. This value equates to $0.2475 \mathrm{~g}$ of $\mathrm{Gd}$ per $\mathrm{cm}$ of rod. Five such rods are in the assembly, and these rods were modeled by having one zone of $\mathrm{Gd}_{2} \mathrm{O}_{3}$ surrounding the fuel-mixture zone. This zone was chosen, for convenience, to be $1 \mathrm{~cm}^{2}$ in area, and the $\mathrm{Gd}_{2} \mathrm{O}_{3}$ density was specified to correspond with the linear density of gadolinium resulting from five rods.

In modeling the burnup of the DU1 sample with HELIOS, a more detailed and sample-specific rendition of the assembly was employed. In the HELIOS model, each fuel pin was a distinct area for which atom densities were calculated separately. The material in each of these areas could be specified separately. Thus fuel pins, fuel-pin clad, moderator, the surrounding Zircaloy box, and the channel moderator were all specified as separate entities with their own materials, densities and temperatures. The HELIOS model assumed that the oxide fuel filled all the space inside the Zircaloy clad. In the SAS2H model, by contrast, the gap between fuel pellet and clad was specified. In both cases the appropriate effective densities were employed. This difference should not be significant and, because fuel may swell during irradiation, it is doubtful that specifying a gap is important. 
The $\mathrm{UO}_{2}$ sample was exposed to five reactor cycles and burned for a total burnup of roughly $57 \mathrm{GWd} / \mathrm{t}$. The power history of the reactor is available in considerable detail. However, for the purposes of the preliminary studies reported here, each one of the five cycles was simulated using a constant power that was equal to the cycle average. The data on the reactor cycles, as used in the simulations, are shown in Table 3 (these values are approximate). More details that are proprietary are available on the reactor power history. However, there are a number of reasons why they were not of great importance to this study. The variability in reactor power level was not very great during any one cycle. Experience with SAS2H indicates that the incorporation of such short-term variation would not noticeably affect the end result (other than in the case of short-lived nuclides). Furthermore, reflecting on a theme mentioned earlier, the practical application of SAS2H will be with spent fuel in situations where detailed data on burnup may not be available. Void-fraction data were also supplied by the reactor operators with the same level of detail as that of the power history. The moderator density was determined from the void fraction, and, to be consistent with the level of detail used with the power history, an average moderator density was used for each one of the five cycles.

Table 3. Power history for the DU1 sample irradiation

\begin{tabular}{ccccc}
\hline Cycle & $\begin{array}{c}\text { Approximate } \\
\text { power } \\
(\mathrm{MW} / \mathrm{t})\end{array}$ & $\begin{array}{c}\text { Approximate } \\
\text { length } \\
(\mathrm{d})\end{array}$ & $\begin{array}{c}\text { Approximate } \\
\text { cumulative } \\
\text { burnup } \\
(\mathrm{MWd} / \mathrm{t})\end{array}$ & $\begin{array}{c}\text { Approximate } \\
\text { downtime } \\
\text { (d) }\end{array}$ \\
\hline 1 & 35 & 330 & 12,000 & 80 \\
2 & 36 & 280 & 22,000 & 50 \\
3 & 40 & 320 & 34,000 & 50 \\
4 & 41 & 320 & 47,000 & 4 \\
5 & 29 & 320 & 57,000 & \\
\hline
\end{tabular}

The reactor power-history data supplied by the reactor operators were estimates deemed appropriate for the location of the $\mathrm{UO}_{2}$ test sample. No uncertainties were quoted for these estimates. The sample composition differed significantly from the rest of the assembly; therefore, sample-specific estimates of burnup were thought to be inaccurate. As an alternative to the operator estimates of burnup, we have used the ${ }^{148} \mathrm{Nd}$ concentration in the samples. The concentration of ${ }^{148} \mathrm{Nd}$ in spent fuel is an accepted method for determining burnup. ${ }^{3,4}$ In the case of the DU1 $\mathrm{UO}_{2}$ sample, the burnup predicted from the ${ }^{148} \mathrm{Nd}$ concentration is $4 \%$ higher than that estimated by the operator (in the case of the DM1 MOX sample, the former is $12 \%$ higher than the latter). So, power levels for DU1 were adjusted upwards by $4 \%$ over those estimated by the operators (cycle times remained the same). The approximate values of power in Table 3 reflect the values based on the ${ }^{148} \mathrm{Nd}$ concentration. Typically, when simulating the burnup of a reactor assembly, ${ }^{148} \mathrm{Nd}$ concentration values would not be available. One may have to be content with operator estimates of burnup in most 
cases. With this reality in mind, we will also report comparisons where operator estimates of burnup have been used for the calculated values. 


\section{COMPARISON OF CALCULATED ACTINIDE CONCENTRATIONS WITH MEASURED VALUES}

Figure 2 shows the results of comparisons between calculated and measured (experimental) values for actinides in the DU1 sample ranging from ${ }^{235} \mathrm{U}$ to ${ }^{246} \mathrm{Cm}$. Results are presented as calculated-to-experimental (C/E) ratios for both SAS2H and HELIOS. The SAS2H values were obtained with what is known within SCALE as the 44-group ENDF/B-V library. The HELIOS model of the BWR used a 34-group library based on ENDF/B-VI. The comparisons were made for the dates on which laboratory concentrations were measured (various dates from three to four years following the end of irradiation). All measurements were reported as a fraction of the final ${ }^{238} \mathrm{U}$ concentration. Note that the only uranium isotopes shown in Fig. 2 are ${ }^{235} U$ and ${ }^{236} U$. The fresh sample was reported as being composed of just ${ }^{235} \mathrm{U}$ and ${ }^{238} \mathrm{U}$. However, the results give reason to believe that some ${ }^{234} U$ was also present. Assuming just ${ }^{235} U$ and ${ }^{238} U$ to be present in the fresh fuel, the prediction for the final ${ }^{234} \mathrm{U}$ concentration is poor, but it can be improved by assuming a small amount to be present in the fresh sample (using standard estimates of ${ }^{234} \mathrm{U}$ concentrations in uranium fuel $^{5}$ ). If ${ }^{234} \mathrm{U}$ was present in the fresh sample, it is also possible that ${ }^{236} \mathrm{U}$ was present, but the amount generated via neutron capture on ${ }^{235} \mathrm{U}$ makes the initial amount insignificant. The reality of enrichment is such that there is always some ${ }^{234} \mathrm{U}$ present in fresh fuel.

In Fig. 2, the nuclides up through ${ }^{242} \mathrm{Pu}$ are reasonably well predicted. HELIOS gives very good prediction for ${ }^{235} \mathrm{U}$ and ${ }^{239} \mathrm{Pu}$, but it is poor for ${ }^{237} \mathrm{~Np}$. In the irradiation process, a series of neutron captures produce plutonium isotopes up through ${ }^{243} \mathrm{Pu}$, which decays to ${ }^{243} \mathrm{Am}$ with a 5-h half-life (see Fig. 3). The relative amounts of these isotopes that are predicted to be in the discharged fuel are plotted in Fig. 4. Referring again to Fig. 2, one sees that the americium concentrations are over predicted in the SAS2H case. Americium-244 is produced via neutron capture on ${ }^{243} \mathrm{Am}$ which leads, in turn, to ${ }^{244} \mathrm{Cm}$ via short decay times. Successive neutron captures then lead to the higher curium isotopes. The measurement uncertainties quoted for most of these nuclides are less than a few percent. However, for ${ }^{243} \mathrm{Cm}$ the measurement uncertainty is quoted as $16 \%$. This large uncertainty associated with ${ }^{243} \mathrm{Cm}$ is not unexpected. Americium and curium remain together as a separated fraction. The americium concentrations can be determined. However, in determining the curium concentrations, the case of ${ }^{243} \mathrm{Cm}$ is unique. It is determined via a gamma line that unfortunately is at the same energy as one from ${ }^{239} \mathrm{~Np}$, which is a decay product of ${ }^{243} \mathrm{Am}$. One must wait for the activities of the ${ }^{243} \mathrm{Am}$ and ${ }^{239} \mathrm{~Np}$ to come into equilibrium and then (knowing the ${ }^{243} \mathrm{Am}$ concentration) determine the contribution from the ${ }^{239} \mathrm{~Np}$. Subtracting the ${ }^{239} \mathrm{~Np}$ contribution from the total gamma count allows one to calculate the ${ }^{243} \mathrm{Cm}$ concentration. However, this process leads to a large uncertainty.

Of somewhat lesser importance is the chain of nuclides starting with ${ }^{241} \mathrm{Am}$ (see Fig. 3). The ${ }^{241} \mathrm{Am}$ is produced from the decay of ${ }^{241} \mathrm{Pu}$. This step leads via neutron capture to ${ }^{242} \mathrm{Am}$ and ${ }^{242 \mathrm{~m}} \mathrm{Am}$. The ${ }^{242 \mathrm{~m}} \mathrm{Am}$ contributes to the ${ }^{243} \mathrm{Am}$, and the ground state of ${ }^{242} \mathrm{Am}$ decays primarily to ${ }^{242} \mathrm{Cm}(17 \%$ decays to ${ }^{242} \mathrm{Pu}$ ). Curium-243 is produced by neutron capture on ${ }^{242} \mathrm{Cm}$, and this contributes to the higher curium isotopes by further neutron-capture processes. The contributions via ${ }^{242} \mathrm{Cm}$ are, however, quite small relative to the contributions that come via the higher plutonium isotopes. In summary, the predictions for all nuclides shown in Fig. 2 are reasonable, with the exception of ${ }^{242 \mathrm{~m}} \mathrm{Am},{ }^{243} \mathrm{Am},{ }^{243} \mathrm{Cm}$, and ${ }^{244} \mathrm{Cm}$ whose concentrations are overpredicted by SAS2H and ${ }^{237} \mathrm{~Np}$, which 
is under predicted by HELIOS. The C/E ratios for the DU1 actinides are shown in numerical form in Table 4.

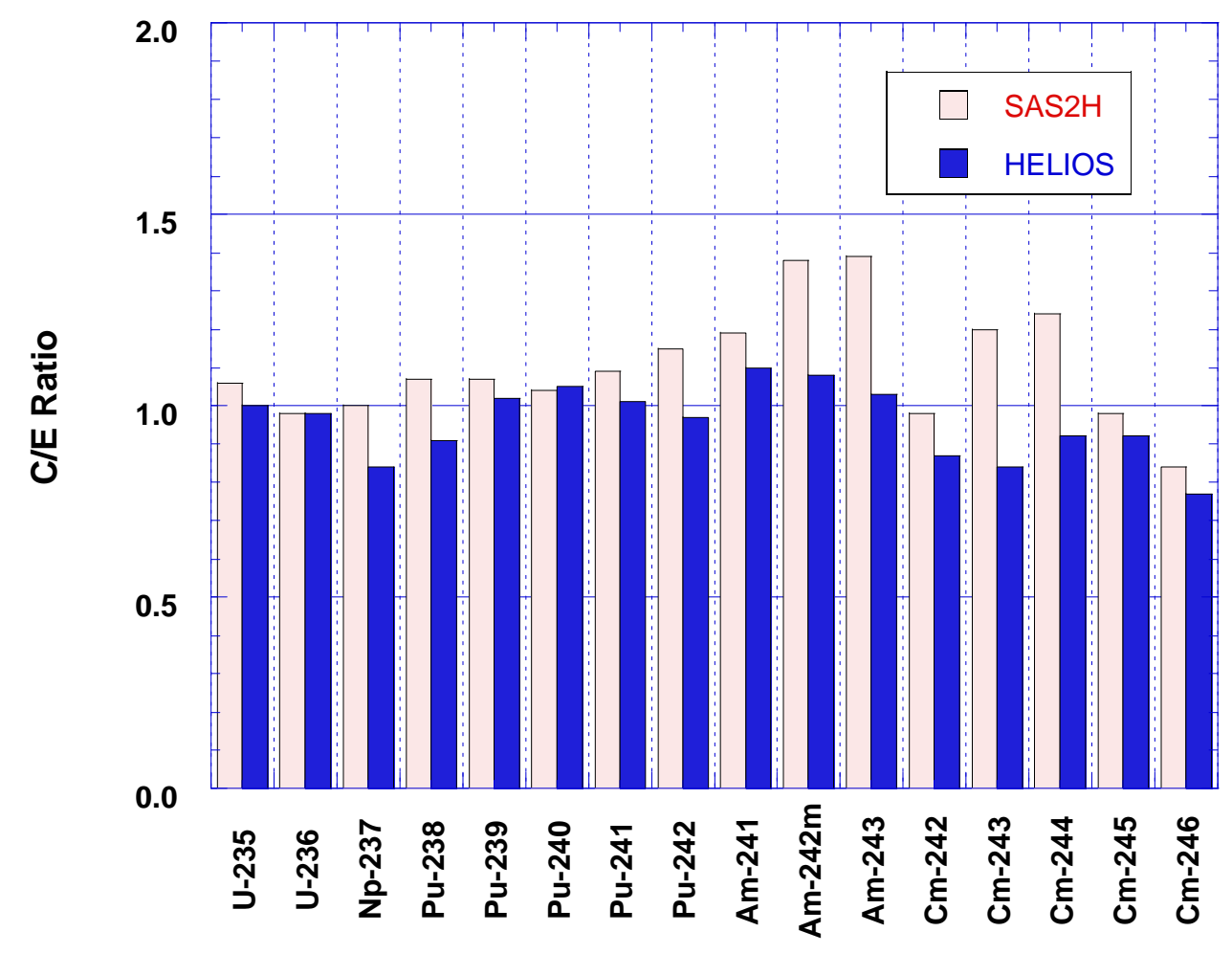

Fig. 2. Calculated-to-experimental ratios for the DU1 sample actinides. 


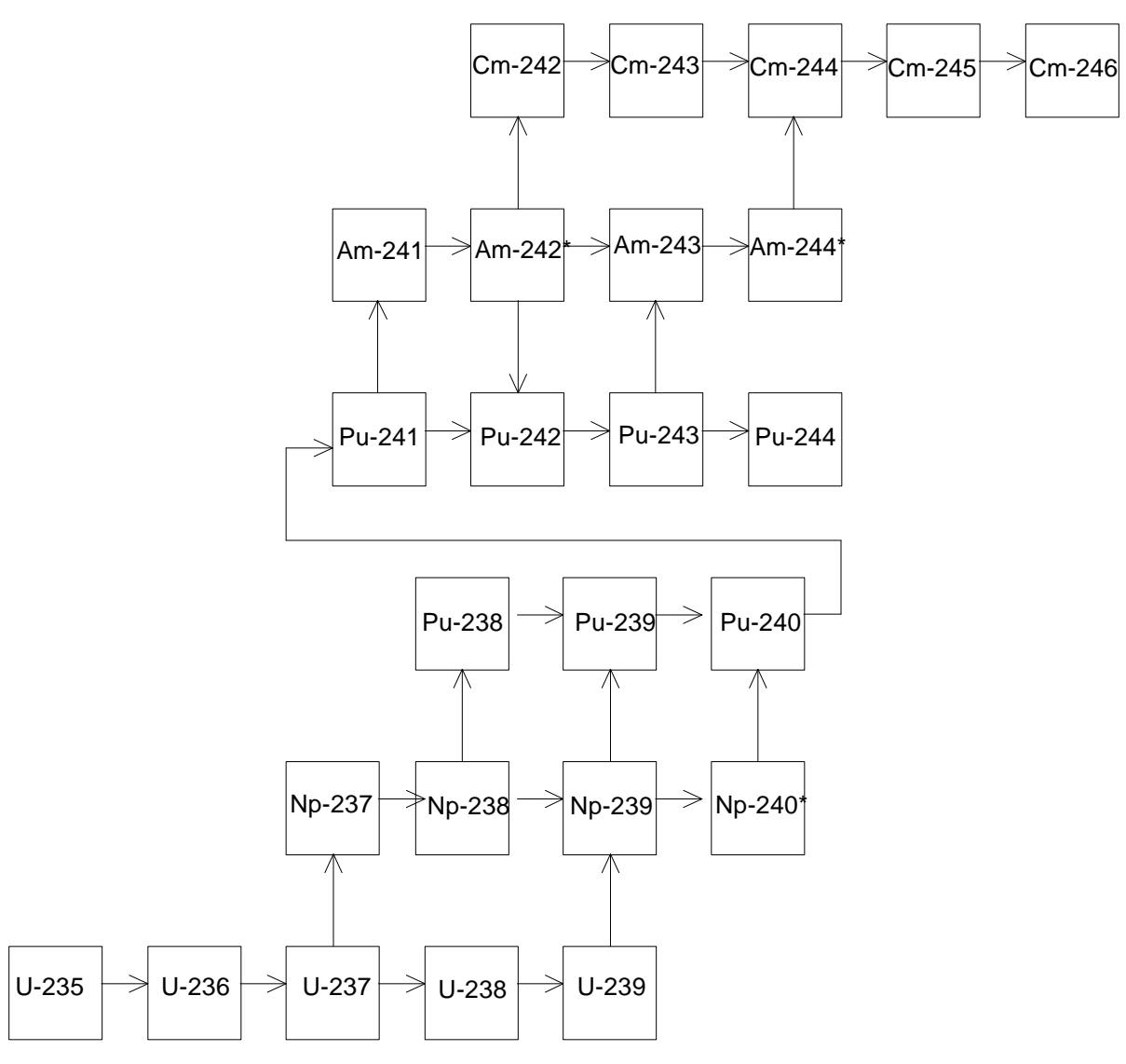

Fig. 3. A schematic representation of the relevant actinides. Horizontal lines are capture; vertical lines represent various beta decay processes. Asterisks indicate the presence of metastable states. 


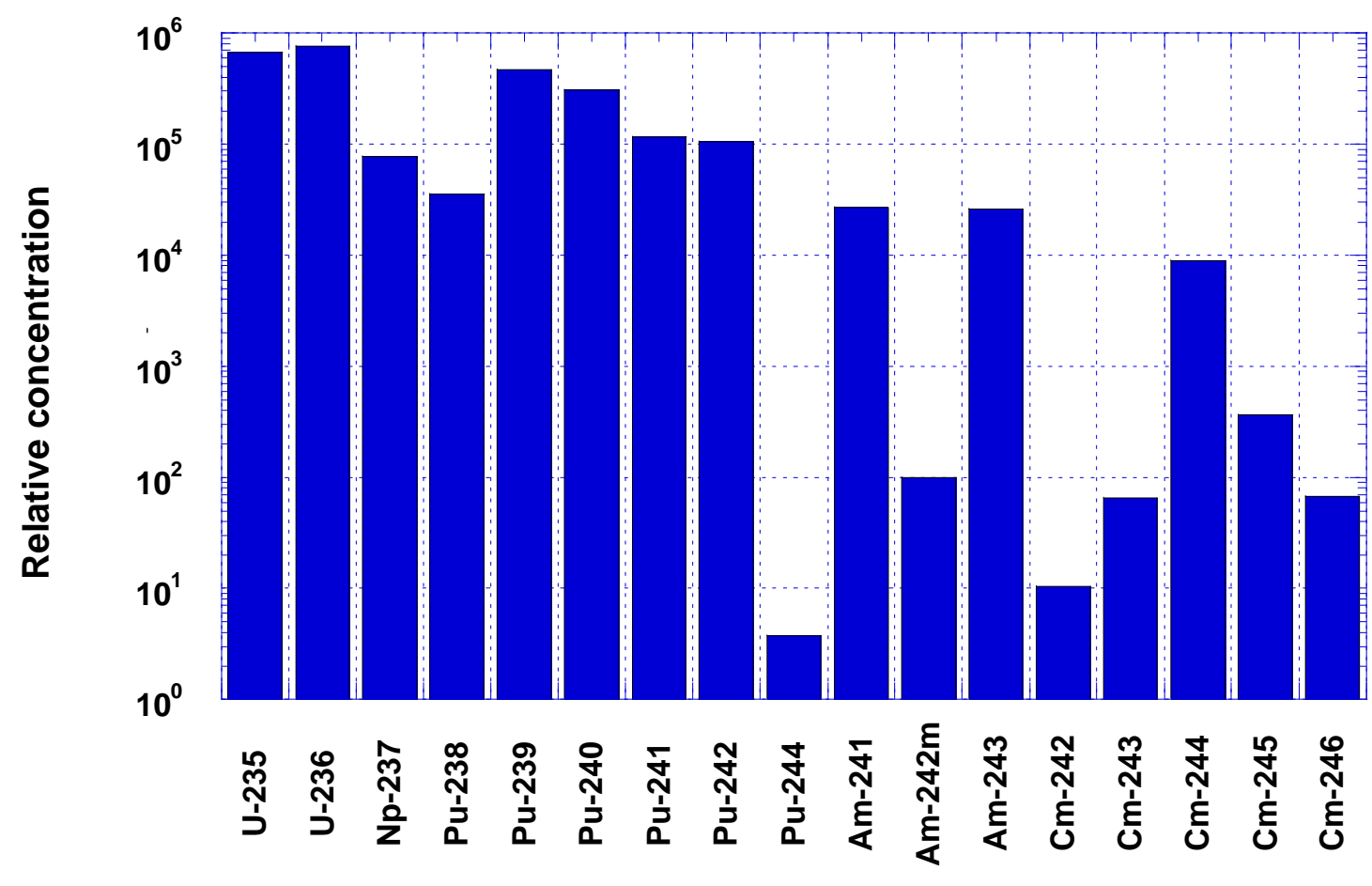

Fig. 4. Calculated concentrations for DU1 actinides shown relative to one another on an arbitrary scale. Because the concentration of ${ }^{244} \mathrm{Pu}$ is so low, it was not considered in these studies. 
Table 4. Calculated-to-experimental ratios for DU1 actinides

\begin{tabular}{lcc}
\hline & SAS2H & HELIOS \\
\hline $\mathrm{U}-235$ & 1.06 & 1.00 \\
$\mathrm{U}-236$ & 0.98 & 0.98 \\
$\mathrm{~Np}-237$ & 1.00 & 0.84 \\
$\mathrm{Pu}-238$ & 1.07 & 0.91 \\
$\mathrm{Pu}-239$ & 1.07 & 1.02 \\
$\mathrm{Pu}-240$ & 1.04 & 1.05 \\
$\mathrm{Pu}-241$ & 1.09 & 1.01 \\
$\mathrm{Pu}-242$ & 1.15 & 0.97 \\
$\mathrm{Am}-241$ & 1.19 & 1.10 \\
$\mathrm{Am}-242 \mathrm{~m}$ & 1.38 & 1.08 \\
$\mathrm{Am}-243$ & 1.39 & 1.03 \\
$\mathrm{Cm}-242$ & 0.98 & 0.87 \\
$\mathrm{Cm}-243$ & 1.20 & 0.84 \\
$\mathrm{Cm}-244$ & 1.24 & 0.92 \\
$\mathrm{Cm}-245$ & 0.98 & 0.92 \\
$\mathrm{Cm}-246$ & 0.84 & 0.77 \\
\hline
\end{tabular}





\section{FISSION-PRODUCT COMPARISONS}

Fission-product results for the $\mathrm{UO}_{2}$ sample are shown in Fig. 5. Values calculated using the SCALE system (SAS2H) and values calculated with HELIOS were each compared with laboratorymeasured values, and the resulting $\mathrm{C} / \mathrm{E}$ ratios are plotted. Again, all concentrations were reported relative to that of ${ }^{238} \mathrm{U}$, and both calculated and experimental values were for the laboratorymeasurement date in all instances. Because the ${ }^{148} \mathrm{Nd}$ concentration was used to obtain an accurate sample burnup estimate, the values for ${ }^{148} \mathrm{Nd}$ in Fig. 5 must, of necessity, be unity. Somewhat high $\mathrm{C} / \mathrm{E}$ values are noted for ${ }^{106} \mathrm{Ru}$ and ${ }^{125} \mathrm{Sb}$. The various samarium and europium results show some scatter, but the remainder of the results are satisfactory. The chemistry laboratory is of the opinion ${ }^{6}$ that some ${ }^{106} \mathrm{Ru}$ and ${ }^{125} \mathrm{Sb}$ remain in the residues from the sample dissolution and, if this is the case, the $\mathrm{C} / \mathrm{E}$ ratios for these nuclides are likely to improve when the residues are analyzed. To date, the residues have not been analyzed. With this level of predictability, it seems that it is possible to make reliable estimates about the radiological properties of spent $\mathrm{UO}_{2}$ fuel from a BWR.

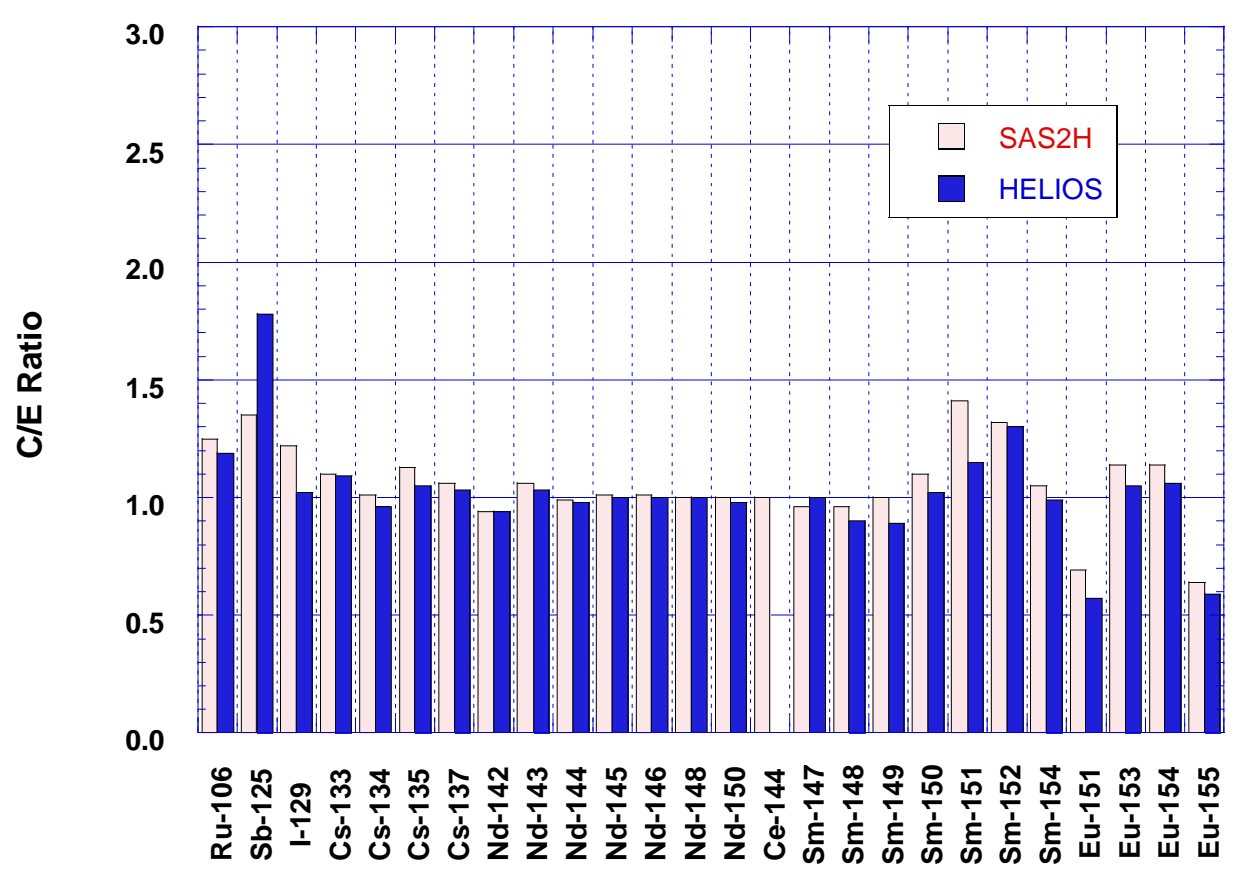

Fig. 5. Calculated-to-experimental ratios for fission products in DU1 sample. A value for ${ }^{144} \mathrm{Ce}$ was not available with HELIOS. 



\section{SENSITIVITY TO BURNUP AND MODERATOR DENSITY}

Simulations such as these depend on the values of many input parameters that are estimated with varying degrees of accuracy. Therefore, discussions of the success of a code as a simulation tool must consider how uncertainties in input data contribute to inaccuracies in simulation results. The possibility of uncertainty in the estimates of burnup has been discussed earlier. For this reason, we have examined the sensitivity of some of the results to variations in burnup. BWR simulations must deal with variability of the moderator density because of axial variations in the void fraction another important source of modeling uncertainty in this work. Therefore, the sensitivity of the results to moderator density was also investigated.

As was explained, the most reliable estimate of the sample burnup was obtained from the

${ }^{148} \mathrm{Nd}$ concentration. The sensitivity to burnup was investigated by examining the ${ }^{235} \mathrm{U}$ and ${ }^{239} \mathrm{Pu}$ concentrations as burnup was varied between $90 \%$ and $110 \%$ of the value derived from ${ }^{148} \mathrm{Nd}$. The results of that study are shown in Fig. 6 . In the case of ${ }^{235} \mathrm{U}$, the concentration is quite sensitive to burnup; but this is not the case for ${ }^{239} \mathrm{Pu}$. These sensitivity studies were carried out with SAS2H, and it seems certain that SAS2H is prone to overpredicting the ${ }^{239} \mathrm{Pu}$ concentrations; however, a $2 \%$ increase in burnup would indicate agreement between computation and experiment in the case of ${ }^{235} \mathrm{U}$. The reactor operator estimate of burnup was $4 \%$ lower than the estimate from the ${ }^{148} \mathrm{Nd}$ concentration. This lower reactor operator estimate of burnup was used to carry out both a separate SAS2H and a separate HELIOS simulation. The results of these two simulations for the actinides are shown in Fig. 7. Both SAS2H and HELIOS show poorer agreement for ${ }^{235} \mathrm{U}$ than in the case of the ${ }^{148} \mathrm{Nd}$-based burnup (Fig. 2). The values for the curium isotopes are generally lower. With the ${ }^{148} \mathrm{Nd}$-based burnup, the HELIOS predictions for the curium isotopes were quite good, which may indicate that this method is indeed a better estimate of burnup than that quoted by the reactor operator. It is noteworthy that there are such marked differences between the simulations where the differences in burnup are only $4 \%$. It seems clear from both sets of simulations, however, that SAS2H tends to overpredict the concentrations for ${ }^{242 \mathrm{~m}} \mathrm{Am},{ }^{243} \mathrm{Am},{ }^{243} \mathrm{Cm}$, and ${ }^{244} \mathrm{Cm}$ for the DU1 sample. Because the DU1 sample was atypical of the surrounding fuel, however, this was a less than ideal case for SAS2H.

Sensitivity to moderator density was investigated by varying the density between $90 \%$ and $110 \%$ of the estimated density used in the simulations. Figure 8 shows the $\mathrm{C} / \mathrm{E}$ ratio for ${ }^{235} \mathrm{U}$ and ${ }^{239} \mathrm{Pu}$ as a function of varying density. For both ${ }^{235} \mathrm{U}$ and ${ }^{239} \mathrm{Pu}$, the calculated value varies by about $1 \%$ for each $1 \%$ variation in moderator density. Given the factors that affect the determination of moderator density, a $5 \%$ uncertainty would be quite possible.

The contribution from uncertainties in the input data should be kept in mind when judging the goodness of a particular simulation or when comparing the results of different simulations. Calculated parameters have been shown to be sensitive to the likely uncertainties in burnup and moderator density. The uncertainty in moderator density is derived from the uncertainty in void fraction. However, uncertainty in moderator temperature will also contribute to uncertainty in moderator density. 


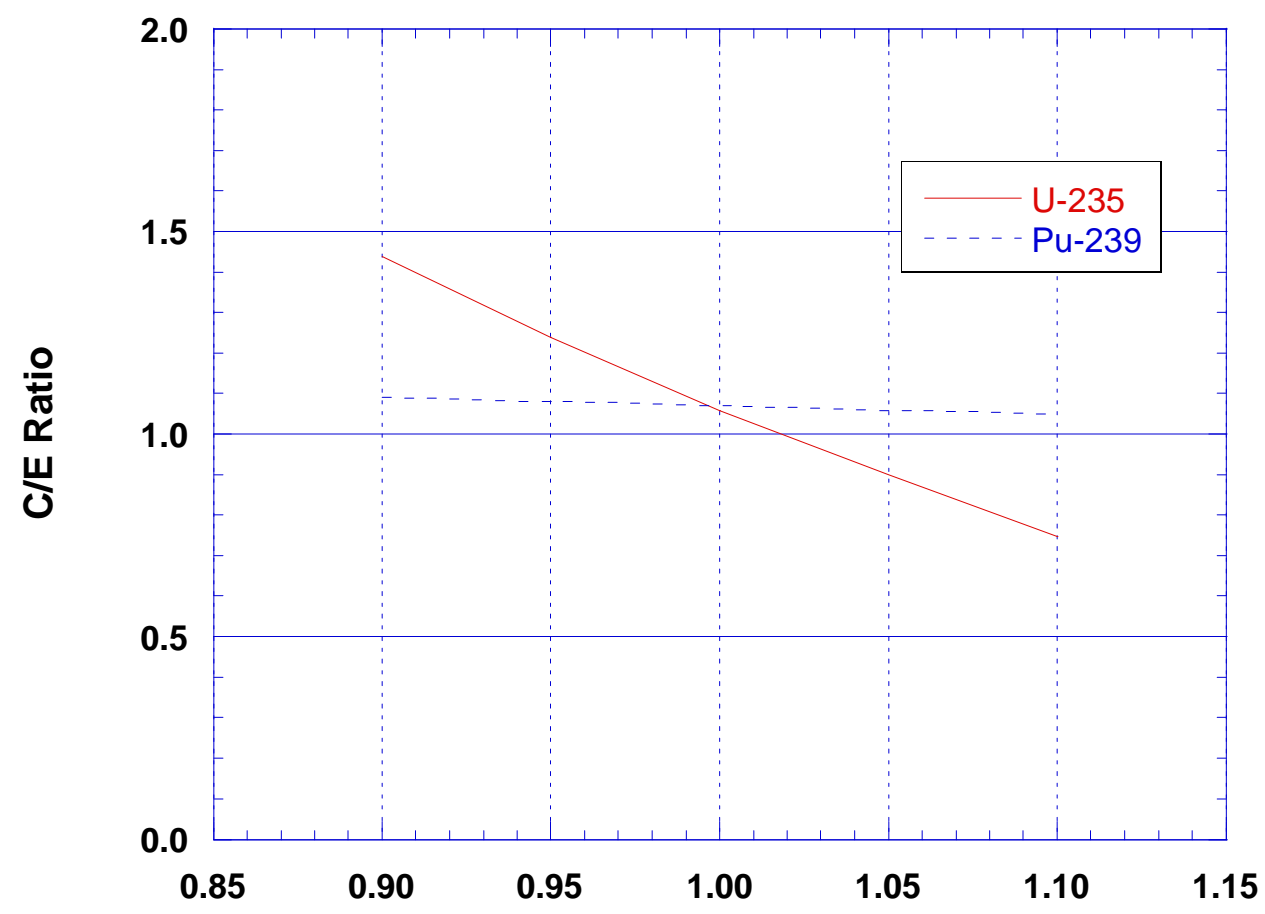

Fractional burnup

Fig. 6. Sensitivity of the ${ }^{235} \mathrm{U}$ and ${ }^{239} \mathrm{Pu}$ concentrations to burnup in the DU1 sample. A fractional burnup of 1.0 corresponds to the ${ }^{148} \mathrm{Nd}$-estimated value. 


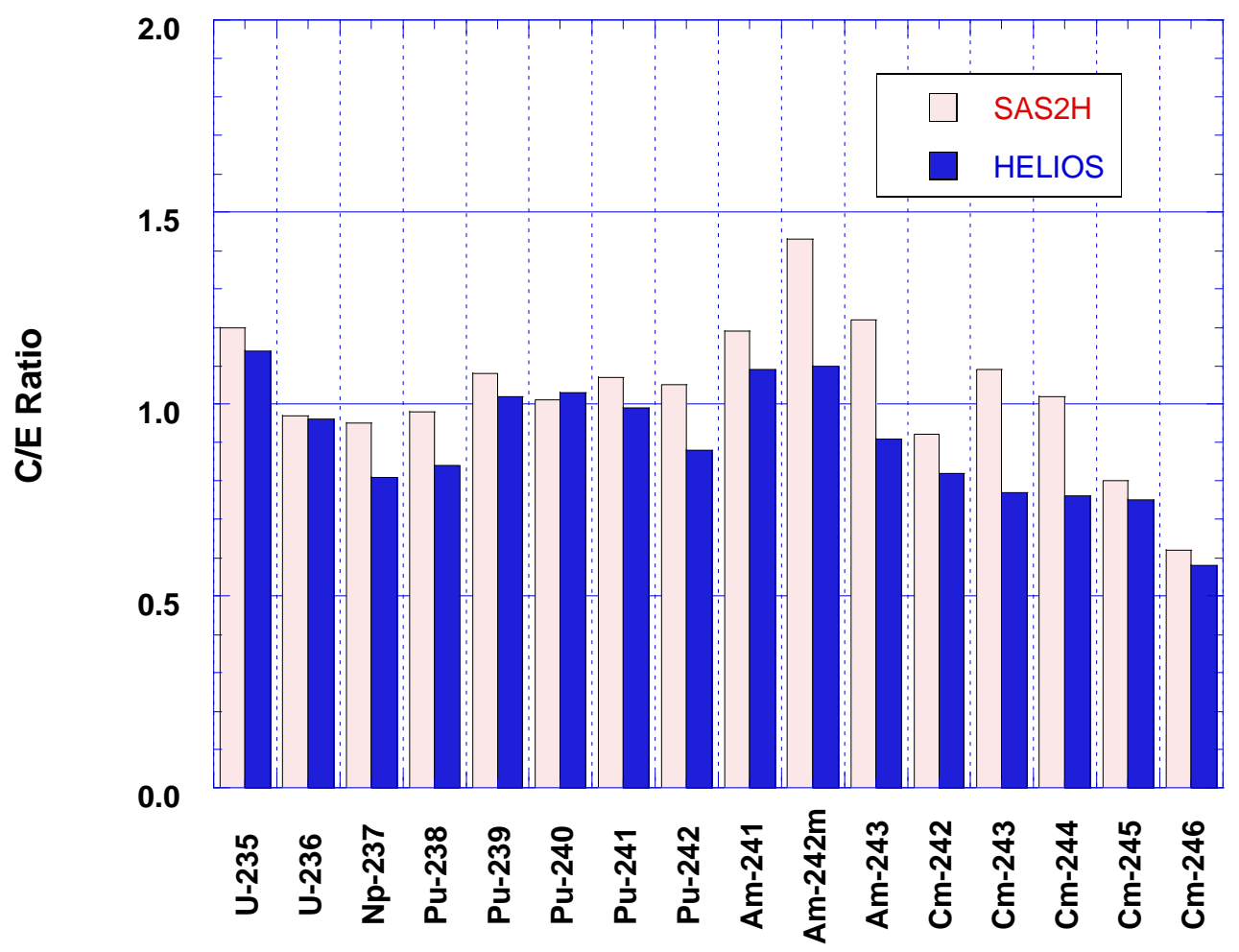

Fig. 7. Calculated-to experimental ratios for the DU1 actinides using the operator estimate of burnup. 


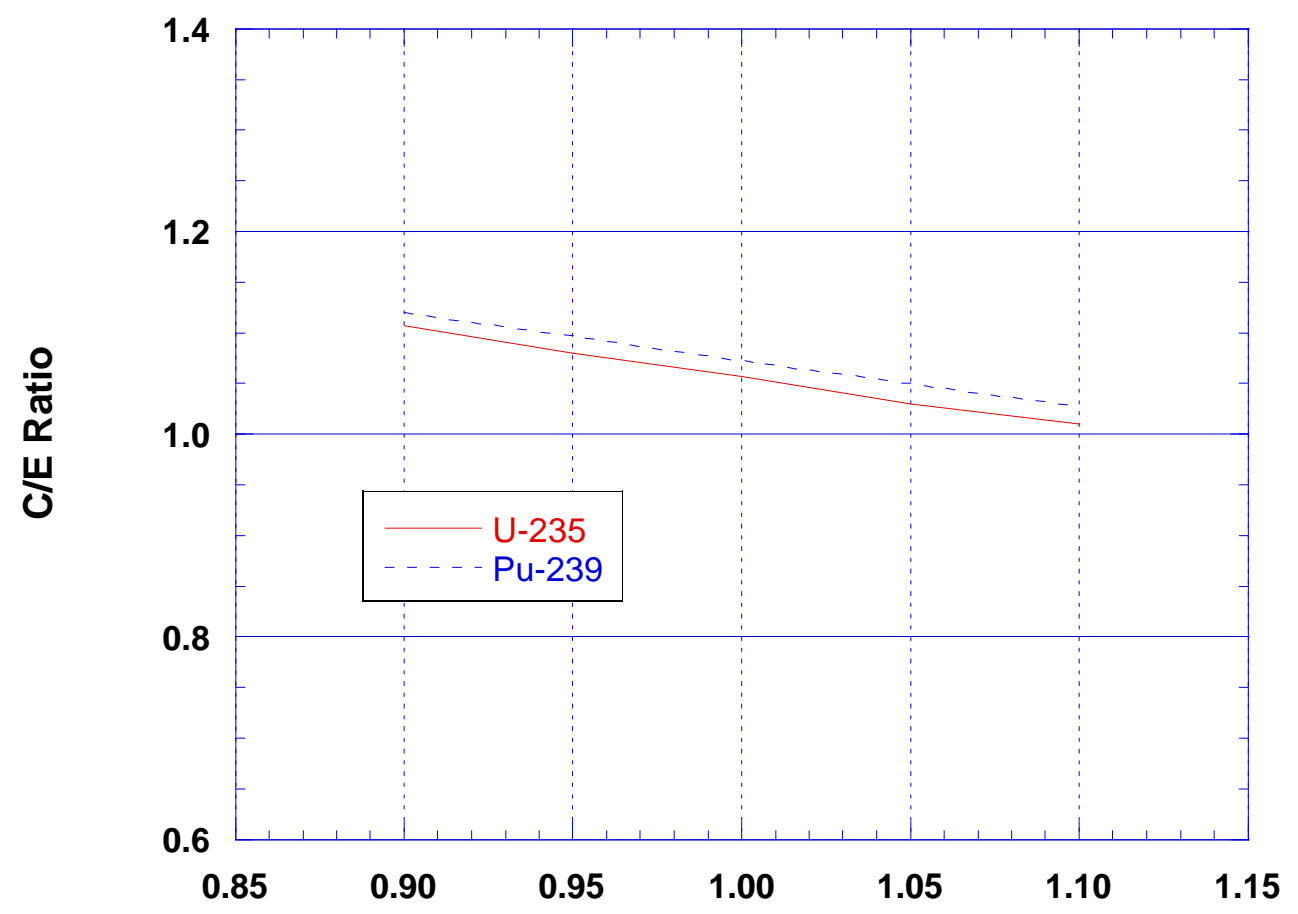

Fractional density

Fig. 8. Sensitivity of the ${ }^{235} \mathrm{U}$ and ${ }^{239} \mathrm{Pu}$ concentrations to the moderator density in SAS2H. A fractional density of 1.0 corresponds to the value used in the simulations. 


\section{OBSERVATIONS}

An alternative SAS2H model would involve the placing of the $\mathrm{Gd}_{2} \mathrm{O}_{3} / \mathrm{UO}_{2}$ inside the fuel that was being studied. This approach has sometimes been adopted in BWR calculations. To this end, a model equal to one-fifth of the assembly was constructed with one $\mathrm{Gd}_{2} \mathrm{O}_{3} / \mathrm{UO}_{2}$ pin forming the central zone (there are five such pins in the assembly). This approach overestimated the ${ }^{235} \mathrm{U}$ and ${ }^{239} \mathrm{Pu}$ concentrations (C/E ratios of 1.20 and 1.08 , respectively) and was therefore not felt to be appropriate for DU1.

Because this work involves a small sample at one location in the reactor core, a possible complication is the accuracy with which one can estimate the burnup at that location. (The HELIOS calculations, in fact, predict that the burnup of the $\mathrm{UO}_{2}$ sample is $37 \%$ and $21 \%$ higher than for $\mathrm{UO}_{2}$ fuel in two neighboring rods.) Even though the overall assembly burnup may be well estimated, its spatial variability may not. The ${ }^{148} \mathrm{Nd}$ concentration was used to estimate sample burnup because it was believed that estimates of sample burnup provided by the reactor operators were subject to some uncertainty and, perhaps more importantly, that uncertainty had not been quantified. Of course, in many practical applications, one is required to estimate spent fuel isotopic composition for some posited value of burnup. Thus, although it is necessary to know the burnup with accuracy in the verification exercise discussed here, in many practical applications the issue of accurate burnup determination might not arise.

As an alternative to the ${ }^{148} \mathrm{Nd}$ concentration, the total neodymium concentration can be used as an indicator of burnup. When the fissile nuclide is ${ }^{235} \mathrm{U}\left(\mathrm{UO}_{2}\right.$ fuel), $0.11 \mathrm{wt} \%$ of $\mathrm{Nd}$ in the spent fuel translates to $10 \mathrm{GWd} / \mathrm{t}$ of burnup ${ }^{7}$. Using this criterion results in a burnup that is $97.2 \%$ of the ${ }^{148} \mathrm{Nd}$-based estimate (however, these two estimates are probably not entirely independent), whereas the operator-based estimate is $96 \%$ of the ${ }^{148} \mathrm{Nd}$-based one. These three estimates of burnup give us confidence that the estimate used in our calculations is within about $4 \%$ of the correct value. We have chosen to use the ${ }^{148} \mathrm{Nd}$-based estimate, and we feel that a comparison of Figs. 2 and 7 shows that this was a good choice because the ${ }^{235} \mathrm{U}$ concentration is overpredicted when one uses the lower value of burnup. In a system where the fissioning nuclide is ${ }^{235} \mathrm{U}$ one might expect the prediction for the final ${ }^{235} \mathrm{U}$ concentration to be accurate if the burnup estimate is accurate (because burnup translates to the number of fissions, and the fissioning energy of ${ }^{235} \mathrm{U}$ is known accurately). This situation would be true for low burnup with $\mathrm{UO}_{2}$ fuel. At higher burnups, ${ }^{239} \mathrm{Pu}$ comes into play. However, if one knows the amount of ${ }^{239} \mathrm{Pu}$ that is being produced, then one should be able to predict the amount of ${ }^{235} \mathrm{U}$ and ${ }^{239} \mathrm{Pu}$ that undergo fission, assuming that one knows the ratio of their fission cross sections with accuracy (and, of course, the fissioning energy of ${ }^{239} \mathrm{Pu}$ is also well known). Assuming one knows the burnup accurately, the most likely difficulty in predicting the final concentrations of ${ }^{235} \mathrm{U}$ and ${ }^{239} \mathrm{Pu}$ is that one does not have accurate predictions for the production of ${ }^{239} \mathrm{Pu}$. A large amount of ${ }^{238} \mathrm{U}$ in the fuel and a small uncertainty in its capture cross section translates into a relatively large uncertainty in the amount of ${ }^{239} \mathrm{Pu}$ produced and thus the amount of fissile nuclei that are available. In turn, the amount of fissile nuclei $\left({ }^{235} \mathrm{U}\right.$ and $\left.{ }^{239} \mathrm{Pu}\right)$ remaining at discharge is difficult to predict. 



\section{SUMMARY AND CONCLUSIONS}

The goal of this work was to investigate the capability of two computer simulation codes to predict spent nuclear fuel composition following high burnup. Using the computer codes, nuclide concentrations in a $\mathrm{UO}_{2}$ sample burned in a BWR were estimated. These estimated nuclide concentrations were then compared with laboratory-measured values. Both actinide and fissionproduct nuclides were investigated. Those fission products that are not cross-section dependent, as expected, are well predicted. Among the 16 actinide nuclide concentrations investigated, five of the $\mathrm{SAS} 2 \mathrm{H}$-calculated concentrations agreed with the measured values to within $5 \%$ and seven of the HELIOS-calculated concentrations did so. Nine predictions were within $10 \%$ in the case of SAS2H and 12 were within $10 \%$ in the case of HELIOS.

The SAS2H sequence from the SCALE code system is 1-D and is designed to give volumeaveraged values. The HELIOS code is 2-D, and thus can calculate values that are specific to a given azimuthal and radial location. The burnup of the $\mathrm{UO}_{2}$ sample in the Dodewaard BWR lends itself reasonably well to analysis by SAS2H. However, because there is a significant variation in enrichment from pin to pin, the configuration is less than ideal. HELIOS should be well capable of such analysis. Overall, the predictability of both codes is reasonable when applied to this particular case. HELIOS, as expected, seems to be more suited for this analysis than does SAS2H. However, a comparison of HELIOS and SAS2H results indicates that the spatial approximations necessary for preparation of the SAS2H model do not greatly impact calculated-to-experimental ratios.

The fuel burnup in this study was quite high. It might be typical of $\mathrm{UO}_{2}$ fuel with an enrichment equivalent to that of the sample but would not be typical for the $\mathrm{UO}_{2}$ fuel in the majority of the assembly. Unfortunately, experimental measurements were not available for lower burnups. It is of interest to know if the predictability of models such as these varies as a function of burnup. 



\section{REFERENCES}

1. SCALE: A Modular Code System for Performing Standardized Computer Analyses for Licensing Evaluation, Vols. I-III, NUREG/CR-0200, Rev. 5 (ORNL/NUREG/CSD-2/R5) (March 1997). Available from Radiation Shielding Information Center as CCC-545.

2. J. J. Casal, R. J. J. Stamm'ler, E. A. Villarino, and A. A. Ferri, HELIOS: Geometric Capabilities of a New Fuel-Assembly Program, International Topical Meeting on Advances in Mathematics, Computations, and Reactor Physics, Pittsburgh, Pa., April 28-May 2 (1991).

3. B. F. Rider, J. P. Peterson, Jr., and C. P. Ruiz, "Determination of Neodymium-148 in Irradiated $\mathrm{UO}_{2}$ as a Measurement of Burnup," Trans. Am. Nucl. Soc. 7, 350 (1964).

4. ASTM, Annual Book of Standards, Vol. 12.01, E321, Standard Test Method for Atom Percent Fission in Uranium and Plutonium Fuel (Neodymium-148 Method), American Society for Testing Materials, West Conshohocken, Pa. 19428 (1996).

5. S. P. Cerne, O. W. Hermann, and R. M. Westfall, Reactivity and Isotopic Composition of Spent PWR Fuel as a Function of Initial Enrichment, Burnup, and Cooling Time, ORNL/CSD/TM-244, Martin Marietta Energy Systems, Inc., Oak Ridge Natl. Lab., 1987.

6. Personal communication from Stefaan Van Winckel, SCK/CEN, Mol, Belgium.

7. C. T. Walker, M. Coquerelle, W. Goll, and R. Manzel, "Irradiation Behaviour of MOX Fuel: Results of an EPMA Investigation," Nucl. Eng. Des. 131, 1-16 (1991). 

ORNL/TM-13687

\section{INTERNAL DISTRIBUTION}

$\begin{aligned} \text { 1. } & \text { B. L. Broadhead } \\ 2-6 . & \text { W. C. Carter } \\ 7 . & \text { B. S. Cowell } \\ 8 . & \text { M. D. DeHart } \\ 9 . & \text { F. C. Difilippo } \\ \text { 10. } & \text { S. R. Greene } \\ 11 . & \text { O. W. Hermann } \\ 12 . & \text { S. A. Hodge } \\ \text { 13. } & \text { M. A. Kuliasha } \\ 14 . & \text { G. E. Michaels } \\ 15-19 . & \text { B. D. Murphy }\end{aligned}$

\author{
20-24. C. V. Parks \\ 25-29. R. T. Primm III \\ 30. R. W. Roussin \\ 31. C. H. Shappert \\ 32. R. M. Westfall \\ 33. R. Q. Wright \\ 34. Central Research Library \\ 35. Laboratory Records, RC \\ 36-37. Laboratory Records for \\ submission to OSTI
}

\section{EXTERNAL DISTRIBUTION}

38. M. L. Anderson, Framatome Cogema Fuels, 1261 Town Center Drive, Las Vegas, Nevada 89134

39. H. R. Canter, Department of Energy, Technical Director, 1000 Independence Ave., SW, Forrestal Building, 3F-043, Washington, DC 20585.

40. T. W. Doering, Framatome Cogema Fuels, 1261 Town Center Drive, Las Vegas, Nevada 89134

41. D. Henderson, Framatome Cogema, 1261 Town Center Drive, Las Vegas, Nevada 89134

42. J. D. Nulton, Office of Fissile Materials Disposition, Department of Energy, MD-3, 1000 Independence Ave., SW, Forrestal Building, Washington, DC 20585.

43. P. T. Rhoads, Department of Energy, 1000 Independence Ave., SW Forrestal Building, 3F-043, Washington, DC 20585.

44. H. Richel, Belgonucleaire, Avenue Ariane, 4 - 1200 Brussels, Belgium.

45-49. D. A. Thomas, Framatome Cogema, 1261 Town Center Drive, Las Vegas, Nevada 89134

50. J. Thompson, Department of Energy, MD-4, 1000 Independence Ave., SW, Forrestal Building, 6G-050, Washington, DC 20585.

51. K. Wright, Framatome Cogema Fuels, 1261 Town Center Drive, Las Vegas, Nevada 89134 
